Review

\title{
The North Pacific Diatom Species Neodenticula seminae in the Modern and Holocene Sediments of the North Atlantic and Arctic
}

\author{
Alexander Matul *(D) and Galina Kh. Kazarina \\ Laboratory of Paleoecology and Biostratigraphy, Marine Geology Department, Shirshov Institute of Oceanology, \\ Russian Academy of Sciences, 36 Nahimovskiy prospect, 117997 Moscow, Russia; gkazarina@mail.ru \\ * Correspondence: amatul@mail.ru; Tel.: +7-499-129-21-72
}

Received: 4 April 2020; Accepted: 5 May 2020; Published: 9 May 2020

check for updates

\begin{abstract}
The paper presents micropaleontological information and observations of the North Pacific diatom species Neodenticula (N.) seminae (Simonsen and Kanaya) Akiba and Yanagisawa in the surface and Holocene sediments from the North Atlantic, Nordic, and Arctic Seas. The compilation of previously published data and new findings of this study on $N$. seminae in the surface sediments shows its broad occurrence as a usual element of the modern diatom microflora in the Nordic, Labrador, and Irminger Seas. The recent migration of N. seminae from its native area, the Subarctic Pacific, reflects the oceanographic shift in the late 1990s as greater transport of the warmer surface Pacific water to the Arctic causes Arctic sea-ice reduction. Micropaleontological studies of the Holocene sediments document the multiple events of $N$. seminae appearance in the Arctic during the latest Pleistocene and Holocene warming intervals. These observations can suggest the events of the increased influence of the North Pacific water on the Arctic environments in the past, not just during the recent warm climate amplification.
\end{abstract}

Keywords: micropaleontology; modern monitoring of climate change; Pacific water in the Arctic and North Atlantic; species migration; Neodenticula seminae; Arctic Holocene paleoecology

\section{Introduction}

The Arctic Ocean and Subarctic North Atlantic areas have distinctive phytoplankton communities as a part of their marine ecosystems, which are now experiencing substantial change related to recent climate warming [1]. During the past 100 years, the average temperatures in the Arctic have increased significantly, by a factor of two compared to the average global rates [2]. The Arctic sea-ice volume and extent has decreased in the past 40 years by three-quarters and one half on average, respectively [3]. Changing marine environments can stress the subarctic/arctic ecosystems allowing the invasive non-native species to disrupt the local food chains and biodiversity [4]. Alien species can be a major component of recent global change transforming local marine ecosystems $[5,6]$.

One of the examples of marine biological invasions in the Arctic, Nordic, and Labrador Seas is a recent occurrence of the native North Pacific diatom species Neodenticula (N.) seminae (Simonsen and Kanaya) Akiba and Yanagisawa [7-9]. Previous biostratigraphic studies of the Quaternary sediments from the Arctic and North Atlantic reported the disappearance of this species from the North Atlantic by the end of the Early Pleistocene, 0.84 million years ago (see literature summary in [8]). Now, it is a prominent component of the diatom assemblages in the Labrador and Nordic Seas (see following text). Micropaleontological studies have exhibited the events of interactions between the North Pacific and North Atlantic during the Pleistocene, e.g., based on radiolarian data [10,11]. The radiolarian species Amphimelissa (A.) setosa (Cleve) was dominant in the interglacial microfaunal assemblages of 
the Subarctic Pacific during the last 1.1 million years, but disappeared there 72,000 years ago [10,11]. Appearance of $A$. setosa in the Middle to Late Pleistocene interglacial sediments of the Northern North Atlantic suggests the multiple connections between the North Pacific and Atlantic realms during the prominent warmings [11]. The final settling of $A$. setosa in the North Atlantic occurred in the Late Pleistocene; now, it is abundant in the Subarctic and Arctic Seas but does not occur in the North Pacific.

Recent studies of Miettinen et al. [9] and Sha et al. [12] exhibited a common to abundant occurrence of N. seminae in the surface sediments of the Fram Strait and Greenland Sea (1-5.7\%), and Labrador Sea (2.18-18.21\%), respectively. In addition to this information, we present new data on observations of $N$. seminae in the surface sediments of the Labrador and Irminger Seas and discuss the environmental changes which could favor its appearance there. In addition, we compile published reports on the occurrence of $N$. seminae in the Holocene sediments of the Arctic and Nordic Seas to exhibit the multiple events of its invasion from the North Pacific to the Arctic possibly during the Holocene warmings. As some of these reports are in Russian, we try to make them accessible to other specialists in this field of study.

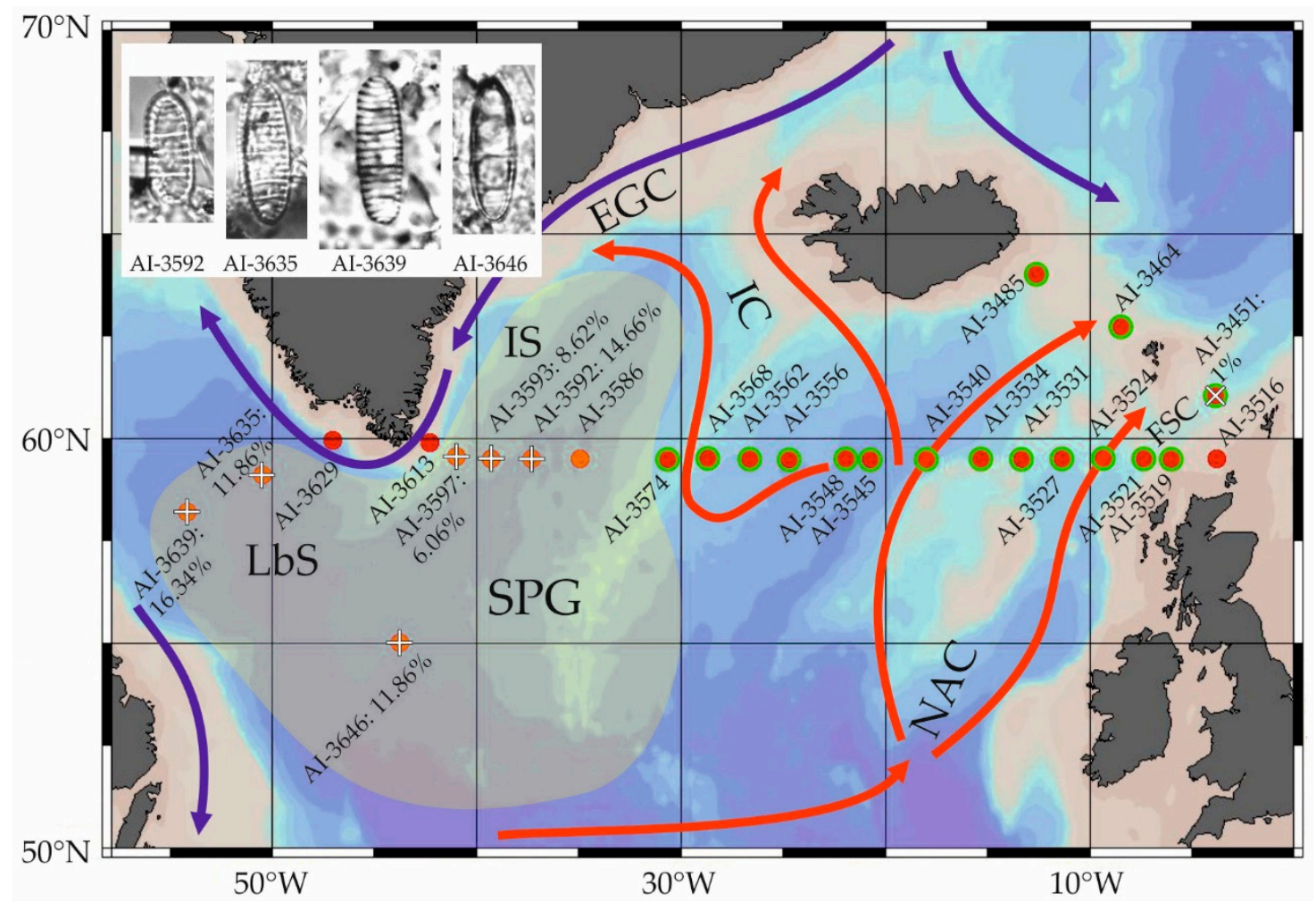

Figure 1. The map of analyzed surface sediment samples (red dots) on the North Atlantic transect at $59.5^{\circ} \mathrm{N}$ (Table A1). The name of the station follows the position of the sample. White crosses mark samples with $N$. seminae; percentages after the station name show N. seminae abundances. Green-framed red dots mark samples with warm-water subtropical diatoms. Red arrows mark warm surface currents, and blue arrows mark cold surface currents. SPG is Subpolar Gyre, LbS is Labrador Sea, IS is Irminger Sea, NAC is North Atlantic Current, IC is Irminger Current, EGC is East Greenland Current, FSC is Faroe-Shetland Channel. The source of the blank map is Ocean Data View software [13]. The microphotographs of $N$. seminae valves are presented.

We compiled data on N. seminae distribution in various sampling material and geographical areas: (1) marine plankton from the Northwestern North Atlantic [7,8,14] and Western Arctic Ocean between the Bering Strait and point of $85^{\circ} \mathrm{N}$ in the Arctic Ocean Basin [15]; (2) sediment trap on Station NAP, the Southern Northwind Abyssal Plain in the Western Arctic Ocean [16]; and (3) the Late Pleistocene and Holocene sediments from the Arctic Ocean and Nordic and Arctic Seas [17-23]. In addition, we report new data on $N$. seminae occurrence in 26 surface sediment samples from a 0-2 cm layer of 
the grab samplers obtained during the 51st cruise of the Russian RV Akademik Ioffe in June-July 2016 on the North Atlantic transect at $59.5^{\circ} \mathrm{N}$ between the Labrador Sea and the Faroe-Shetland Channel (Figure 1; Table A1).

The map of N. seminae distribution in the surface sediments of the North Atlantic and Nordic Seas (Figure 2a) presents our data on the $59.5^{\circ} \mathrm{N}$ transect together with published data of Sha et al. [12] on the Labrador Sea and Miettinen et al. [9] on the Nordic Seas.

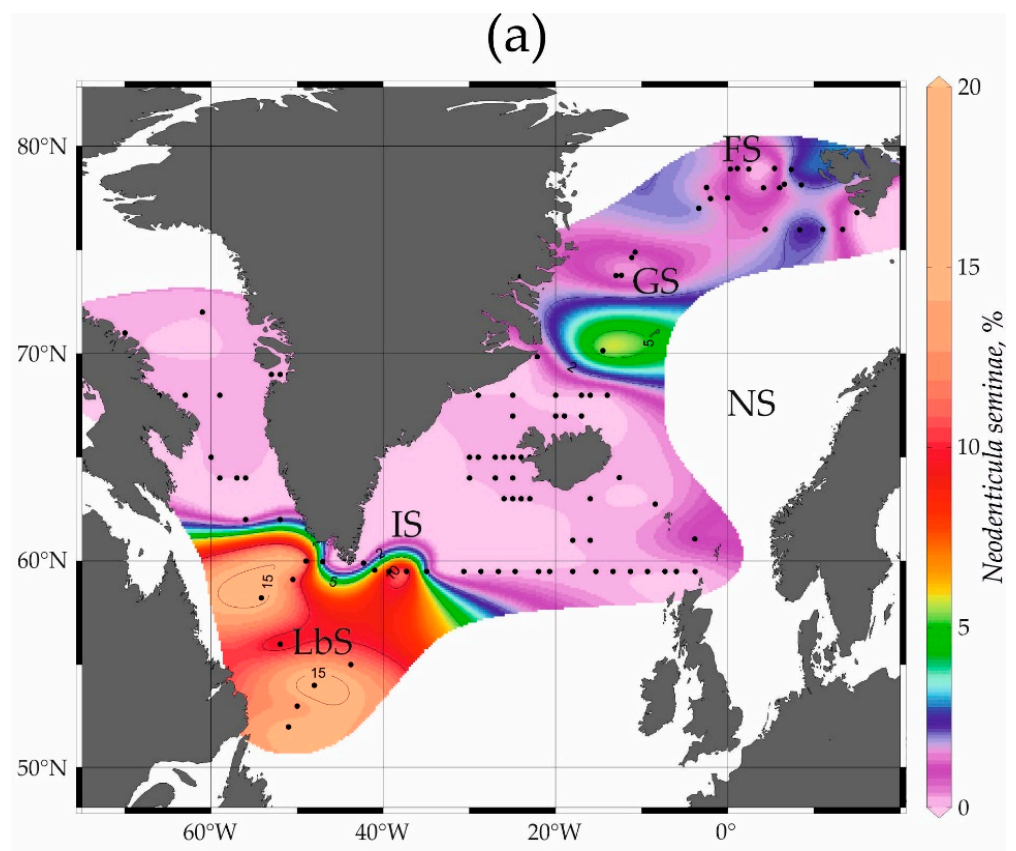

(b)

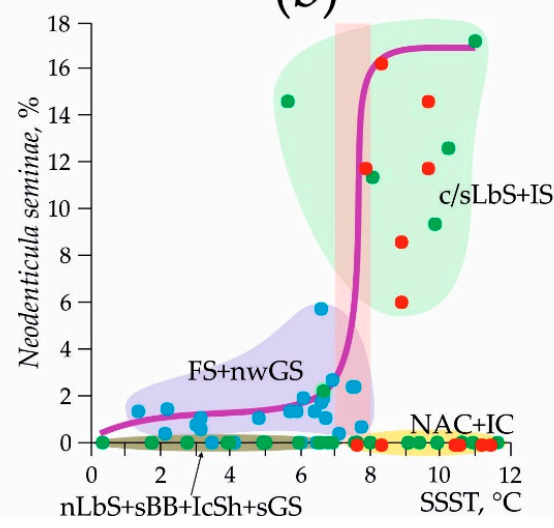

Figure 2. (a) is the distribution of $N$. seminae in the surface sediment samples of the Nordic and Labrador Seas, data from $[9,12]$ and this study (Table A1). Black dots mark diatom samples. (b) is a plot of N. seminae percentages in the surface sediments, data from $[9,12]$ and this study (Table A1), versus SSST (Summer Sea Surface Temperature). SSST for the period of 2007-2017 is extracted from the World Ocean Atlas 2018 [24]. Purple line approximates distribution of N. seminae greatest percentages. Transparent red vertical bar marks a rapid change of $N$. seminae abundances. Colored fields mark geographical areas: LbS is Labrador Sea, c/sLbS is central/southern Labrador Sea, nLbS is northern Labrador Sea, IS is Irminger Sea, GS is Greenland Sea, nwGs is northwestern Greenland Sea, sGs is southern Greenland Sea, sBB is southern Baffin Bay, NS is Norwegian Sea, FS is Fram Strait, IcSh is Iceland Shelf, NAC is North Atlantic Current, IC is Irminger Current. Blue, green, and red dots mark data from [9,12], and this study (Table A1), respectively. The map is created by Ocean Data View software [13]. 
Plot "N. seminae percentages in the surface sediments versus SSST (Summer Sea Surface Temperature)" in Figure $2 \mathrm{~b}$ provides a view of the temperature impact on the distribution of this species based on data from [9,12] and this study (Table A1). Data on SSST for the period of 2007-2017 are from the World Ocean Atlas 2018 [24].

\section{Diatom Species Neodenticula seminae in the Modern Ocean}

Figures 1, 2a and 3 present visual information on the occurrence of N. seminae in the modern Subarctic North Atlantic and Arctic Seas.

The native area of the modern distribution of the diatom species Neodenticula seminae (Simonsen and Kanaya) Akiba and Yanagisawa is the Subarctic Pacific with its marginal Bering, Okhotsk, and Japan seas. Semina [25] found N. seminae (= Denticula marina) to be common in the plankton of the Bering Sea and the open Northwestern Subarctic Pacific. Karohji [26] documented its high abundances (as Denticula sp.) up to $37-47 \%$ in the living diatom associations from the Bering Sea, Gulf of Alaska, and Northwestern Subarctic Pacific. The work of Taniguchi et al. [27] presented similar data. Alexander and Cooney [28] summarized the available information on the plankton studies in the Bering Sea and, based on the report of Phifer [29], noted Denticula seminae was present in the Bering Sea and Bering Strait plankton samples. However, the original work of Phifer [29] does not provide such data. Recent publications of, e.g., Aizawa et al. [30] and Wang et al. [31] confirm the abundant occurrence of $N$. seminae in the North Pacific plankton.

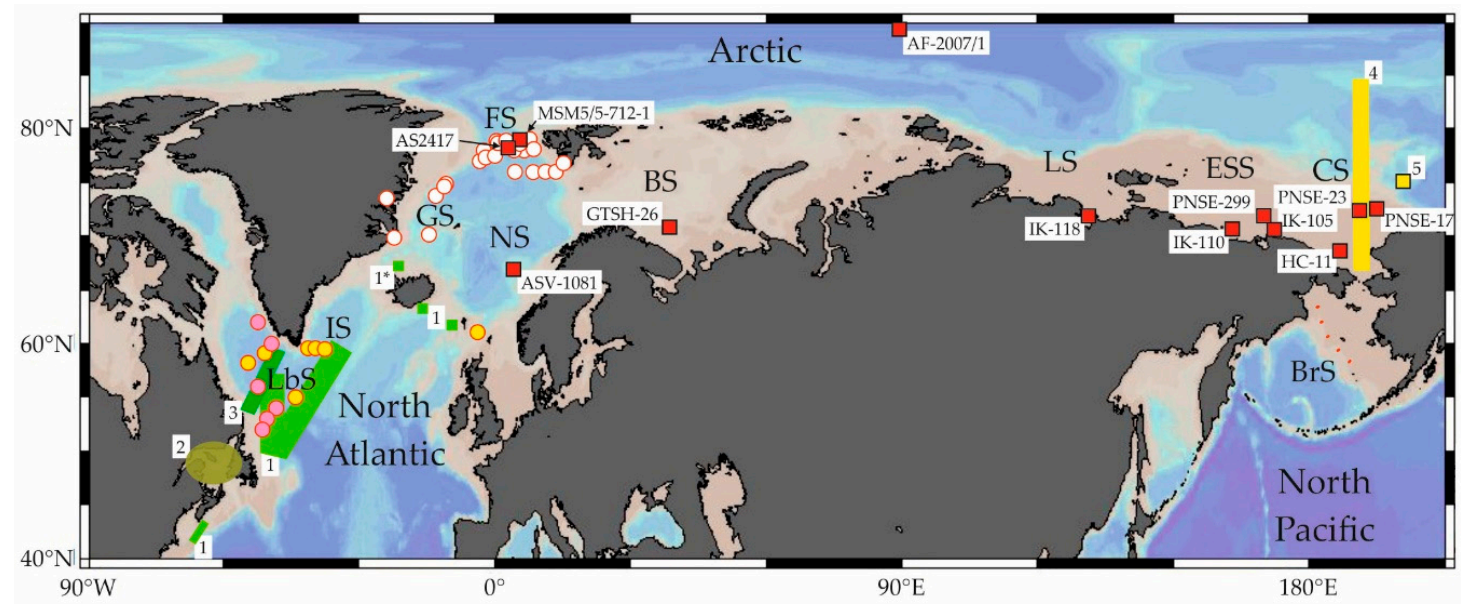

Figure 3. Observations of $N$. seminae in the plankton, sediment trap, surface, and Holocene sediment samples in the Arctic Ocean and North Atlantic. Plankton samples: 1 as green bars and squares, $1^{*}$ as green square, 2 as a greenish oval, 3 as a dark-green bar, and 4 as yellow bar $[7,8,14,15]$. Sediment trap NAP samples: 5 as black-framed yellow square [16]. Surface sediment samples: red-framed white-, yellow-, and rose dots [9,12] and this study (Table A1).Holocene sediment cores: black-framed red dots with names on the white background [17-23,32]. LbS is Labrador Sea, IS is Irminger Sea, GS is Greenland Sea, NS is Norwegian Sea, FS is Fram Strait, BS is Barents Sea, LS is Laptev Sea, ESS is East-Siberian Sea, CS is Chukchi Sea, BrS is Bering Sea. Red arrows in Bering Sea show the northeastern limit of $N$. seminae permanent occurrence in surface sediments of the North Pacific (data mostly from the 1970s) [33]. The source of the blank map is Ocean Data View software [13].

In the mid-1980s, Takahashi [34] first documented the abundant fluxes of N. seminae in the sediment traps of the Subarctic Pacific. Various studies of the diatom samples from 18 sediment traps in the Subarctic and transitional (Subarctic/Subtropical) Pacific exhibited massive occurrence of this species in the phytoplankton during the most productive seasons [35-41]. Following the publication by Semina [25], in numerous reports published during the period of 1960s-2010s, N. seminae was referred to as either a common or dominant species in the diatom assemblages from the surface sediments of the Subarctic Pacific [42-50]. 
As concluded by Takahashi [36], N. seminae is an indicator species of primary productivity in the nutrient-rich and well-mixed surface waters of the Subarctic Pacific showing both spring and autumn peaks of its highest development in the siliceous phytoplankton communities.

Reid et al. [8] reported the first abundant occurrence of $N$. seminae in Labrador Sea plankton in May 1999. Another case of N. seminae appearance in the North Atlantic was the dominance of this species among the planktic diatoms in the Gulf of St. Lawrence, Eastern Canada, in April 2001 [7]. Later, Fragoso [14] documented N. seminae from plankton studies in the Labrador Sea in May-June 2011-2014. Studies of Poulin et al. [51] revealed no significant morphological and phylogenetic differences between N. seminae populations in the Subarctic Pacific and Gulf of St. Lawrence. Miettinen et al. [9] first published data on the observations of $N$. seminae in abundances of $0.3-5.7 \%$ from the surface sediments of the Fram Strait and Nordic Seas based on the study of samples collected during 2006-2008. Sha et al. [12] next reported the abundant occurrence of $2-18 \%$ N. seminae in the surface sediments of the Labrador Sea sampled in 2008. In our new surface sediment samples, which were collected in 2016, the abundance of N. seminae reached $6-16 \%$ at six stations in the Labrador and Irminger Seas (Figures 1 and 2a; Table A1). In the same area, Sha et al. [12] found N. seminae with abundances of $2 \%$ to $18 \%$ at seven stations. All stations with N. seminae observations are within the Subpolar Gyre west of ca. $35^{\circ} \mathrm{W}$ in the Northwestern North Atlantic. N. seminae occurs in the assemblages with both abundant and non-abundant, well-preserved cold-water north-boreal diatom flora dominated by Rhizosolenia hebetata Bailey, Thalassiosira antarctica Comber var. borealis, Thalassiosira gravida Cleve, Actinocyclus curvatulus Janish, and Coscinodiscus marginatus Ehr. In samples with N. seminae, sporadic specimens of the warm-water or sea-ice diatoms occur. Overall, we find no clear relationship between N. seminae occurrences in the North Atlantic surface sediments and the appearance of particular diatom taxa. There are no indications of the redeposition of the older diatom forms. Diatom assemblages in surface sediments east of approximately $35^{\circ} \mathrm{W}$ on the North Atlantic transect at $59.5^{\circ} \mathrm{N}$ (in Figure 1 , green-framed red dots) contain the warm-water subtropical species Hemidiscus cuneiformis Wallich., Rhizosolenia bergonii Perag., Roperia tesselata (Roper) Grun., Shionodiscus oestrupii (Ostenf.) Alverson, Kang and Terriot. The observations of these species reflect an influence of warmer waters of the North Atlantic and Irminger Currents. N. seminae does not occur in surface sediments east of approximately $35^{\circ} \mathrm{W}$ on the North Atlantic transect at $59.5^{\circ} \mathrm{N}$ with the warmer temperate surface waters.

As Kazarina and Yushina [47] and Ren et al. [33] proposed, the sea surface temperature of the highest N. seminae abundances in its native Pacific area ranges between 6 and $11^{\circ} \mathrm{C}$ (mean annual sea surface temperature), and 8 and $15^{\circ} \mathrm{C}$ (summer sea surface temperature). In the Subarctic Pacific, the species disappears from the diatom assemblages at places where sea surface temperature decreases below $5-6{ }^{\circ} \mathrm{C}$. Figure $2 \mathrm{~b}$ shows the same pattern of the temperature impact on $N$. seminae distribution in the North Atlantic samples. In addition to the temperature, the habitat in the subarctic deep-sea basins and on the continental slopes, but not on the shelf, can be preferable for $N$. seminae as, e.g., maps in [33] demonstrate. The coldest-water and shallow-water environments in the northernmost Beringia, Northern Labrador Sea, and on the Greenland/Iceland shelves seem to be not suitable for N. seminae: its percentages drop there to zero ([33]; Figure 2a in this study).

In addition to the Nordic, Labrador, and Irminger Seas, N. seminae now appears in the Chukchi Sea. Wang et al. [15] found it (without reporting its specific abundance) in the plankton samples to the north of the Bering Strait up to the point of $85^{\circ} \mathrm{N}$. The species sporadically appeared in the sediment trap samples of 2010-2012 at station NAP in the Southern Northwind Abyssal Plain in the Western Arctic Ocean [16].

\section{Diatom Species Neodenticula seminae in the Holocene Sediments of the Nordic and Arctic Seas}

From the summary of Reid et al. [8], N. seminae was a usual component of the Quaternary microfossil assemblages in the North Atlantic within the time interval of 1.2 to 0.84 million years ago before its disappearance in this region. Many publications on the Late Pleistocene and Holocene micropaleontology of the North Atlantic and Nordic Seas did not report N. seminae in the sedimentary 
records, e.g., Koç Karpuz and Schrader [52] and Koç Karpuz and Jansen [53] for the Greenland, Iceland, and Norwegian Seas; Andersen et al. [54] for the Reykjanes Ridge and the North Iceland and East Greenland shelves; Witak et al. [55] for the Reykjanes Ridge and the Faroe Skalafjord; Witon et al. [56] for the Faroe fjords; Ran et al. [57] for the North Iceland shelf; Krawczyk et al. [58] and Li et al. [59] for Disco Bay of West Greenland; and Oksman [60] for the Baffin Bay and Isvika Bay on the Northern Svalbard. However, some studies undertaken during the past two decades document observations of this species in the latest Pleistocene and Holocene sediments from various places in the Nordic and Arctic Seas.

Figure 3 shows stations in the Nordic and Arctic Seas with N. seminae observations in the Late Pleistocene and Holocene sediments. Polyakova [17] made extensive studies of the diatoms in the Late Cenozoic (including the Late Pleistocene and Holocene) sediments of the Eurasian Arctic Seas. She observed sporadic specimens of N. seminae in the early Holocene sediments on the Kanin Rise in the Southern Barents Sea and in the middle to late Holocene sediments on the shelf of the East Siberian and Chukchi Seas. Obrezkova and Tsoy [32] and Tsoy and Obrezkova [21] documented the appearance of the species in the middle to late Holocene units of the sediment cores from the Southern Laptev and Southern East Siberian Seas. The late Holocene sediments on the North Pole [18] contain N. seminae alongside the species-rich boreal coccoliths and planktic foraminiferas. Mukhina and Dmitrenko [19] found N. seminae in the abundant diatom assemblages, composed of the arctic, boreal, and some subtropical species, from the supposed Bølling-Allerød sediments on the Vøring Plateau, the Norwegian Sea. All these authors propose the appearance of N. seminae within the intervals of warmer environmental conditions. However, the authors mentioned above do not provide a reliable age model, supported by direct radiocarbon dating; the sediment core chronology is based on the lithoand biostratigraphy combined with a correlation with the well-dated paleoclimatic archives.

Bylinskaya et al. [20] presented the distribution of the microfossils in the Late Pleistocene sediments of the Eastern Fram Strait. They used the AMS (Accelerated Mass Spectrometry) radiocarbon dating and the oxygen-isotopic data for the core chronology and detected N. seminae within the uppermost glacial marine oxygen-isotope stage 2 just prior to the onset of the Holocene. The ${ }^{210} \mathrm{~Pb}$ and AMS ${ }^{14}$ C-data allowed Tsoy et al. [22] to make a detailed microfossil study of the last 2300 years on the Southwestern Chukchi Sea shelf. N. seminae was not abundant or dominant, but a stable component of the diatom assemblages during this time interval and disappeared just within the coldest intervals, such as the Little Ice Age and Dark Ages Cooling.

Matul et al. [23] documented the appearance of $N$. seminae in the well-dated sediment core MSM5/5-712-1 from the Eastern Fram Strait. The paleoenvironmental record of the core covers the past 2000 years with time resolution of studied sediment samples between 37 and 54 years. Sporadic N. seminae specimens occurred at time levels of 173 CE (within the Roman Warm Period (RWP)) and 1989 CE (within the Recent Warming (RW)). The later part of the RWP between 0 and 440 CE in the core MSM5/5-712-1 is marked by the abundant occurrence (from 25-30\% to 70-90\%) of the warm-water diatom Coscinodiscus radiatus Ehr. and presence (1-4\%) of the subtropical species Roperia tesselata (Roper) Grunow, Shionodiscus oestrupii (Ostenfeld) Hasle, and Ethmodiscus rex (Wallich) Hendey. Compared to the RWP, the RW interval (from $1730 \mathrm{CE}$ ) contains the abundant diatom assemblages with a prevalence of the cold-water productivity taxa Thalassiosira gravida Cleve/Thalassiosira antarctica Comber resting spores (up to 40-45\%) and warmer-water Thalassiosira gravida Cleve/Thalassiosira antarctica Comber vegetative cells (up to 40\%). N. seminae appeared in the core MSM5/5-712-1 during both RWP and RW warmings but RWP was more pronounced in the Eastern Fram Strait. The late Holocene dinocyst-based paleoreconstructions for the Fram Strait close to the core MSM5/5-712-1 show an obvious maximum of the sea surface temperature during RWP 0-200 CE; sea-ice cover was similar to that during RW [61]. Werner et al. [62], for the core MSM5/5-712-1, described higher subsurface temperatures and greater advection of the warmer water in the area during the time interval of 100 to 300 CE. Such data can support our conclusion on the appearance of N. seminae in the Fram Strait during the prominent warming of the Roman time. Occurrence of N. seminae in the core MSM5/5-712-1 
at the time level of 1989 CE precedes a major hydrological shift in the Northern Hemisphere at the end of the 1990s which initiated the species migration to the North Atlantic (see discussion in the next section). The most recent observation of $N$. seminae in the core MSM5/5-712-1 is from time level of 1989 CE. The age model of this core was developed by Spielhagen et al. [63] on AMS ${ }^{14}$ C-datings with the best $1 \sigma$ error to be as high as \pm 23 calendar years. Thus, true age assignment of sample with N. seminae (1989 CE) can be different, and a strong relationship between this $N$. seminae occurrence and a definite climatic event within RW should be questioned. However, N. seminae observation at 1989 CE is very close to the event of clear negative anomalies of Arctic sea-ice extent in 1990 (Figure 4a). As model simulations show [64], the trend in negative anomalies of the Arctic sea-ice extent started from 1979-1980 and increased between 1986 and 1992 both in warm and cold seasons. Anthropogenic signals in the Arctic ice change became stably detectable from the early 1990s [64,65].

\section{Migration of the Native North Pacific Diatom Species Neodenticula seminae to the North Atlantic as a possible Reflection of the Global Climate Change}

Publications on the diatom assemblages from the surface sediments of the subarctic North Atlantic, Nordic, and Arctic Seas, which were obtained before the 2000s, did not report observations of N. seminae (e.g., [52,54,66-69]). The appearance of N. seminae in the plankton and modern sediment records followed an oceanographic shift in the Northern Hemisphere from the end of the 1990s (Figure 4a).

A migration of N. seminae to the Arctic and North Atlantic must proceed with the surface waters via the shallow Bering Strait. Although the total transport of the North Pacific water in the Arctic is generally not high, it increased in volume between 2002 and 2015 up to 1.2 Sv [70] compared to the previous rates of 0.78 to $0.83 \mathrm{~Sv}$ between 1946 and the late 1990s [71,72]. The hydrological observations in the Chukchi Sea, Beaufort Sea, and Canadian Basin exhibited an increase of the regional surface sea temperature starting from the late 1990s [73]. In the 2000s, the temperature of the surface Pacific Summer Water and Pacific Winter Water, entering the Chukchi Sea via the Bering Strait, reached values of 4-6.5 ${ }^{\circ} \mathrm{C}$ and $3{ }^{\circ} \mathrm{C}$, respectively, causing a sharp reduction of the seasonal sea ice in the Western Arctic [74]). At the same time, primary productivity in the Pacific sector of the Arctic increased by factor of eight from 1959-1960 to 2000-2014 [75]. The Eastern Arctic areas also experienced a major oceanographic shift in the late 1990s. The temperature and salinity anomalies in the water layer of 10-200 $\mathrm{m}$ in the Nordic, Barents, and Labrador Seas became stably positive [76]. During the past 40 years, the sea-ice volume in the Arctic dropped by three-quarters, which means a decrease in the sea-ice extent by one half on average [3]. From 1998, the sea-ice extent anomalies are progressively negative from $-5 \%$ to $-30 \%$ and sometimes $-50 \%$ compared to the multidecadal average (Figure $4 \mathrm{a}$ ).

A hydrological consequence of the recent climatic changes is an increase in the inflow of the Pacific water in the Arctic. Based on the nitrate/phosphate ratio, 90\% of the upper mixed layer in the Northeast Water Polynya at the Northeastern Greenland has a North Pacific origin [77]. Almost all water in the passages of the Canadian Arctic Archipelago toward the North Atlantic (including Hudson Bay, Western Baffin Bay, along Labrador, and in the Grand Bank area), and some water in the Fram Strait and along East Greenland down to $66^{\circ} \mathrm{N}$ originates from the Pacific $[9,78,79]$. Therefore, we could suggest the main path of the modern dispersal N. seminae is from the Bering Sea via the Bering Strait along the Canadian shore, then through the Canadian Archipelago passages toward the Labrador Sea, and with the East Greenland Current toward the Fram Strait and the Northwestern Greenland Sea. 


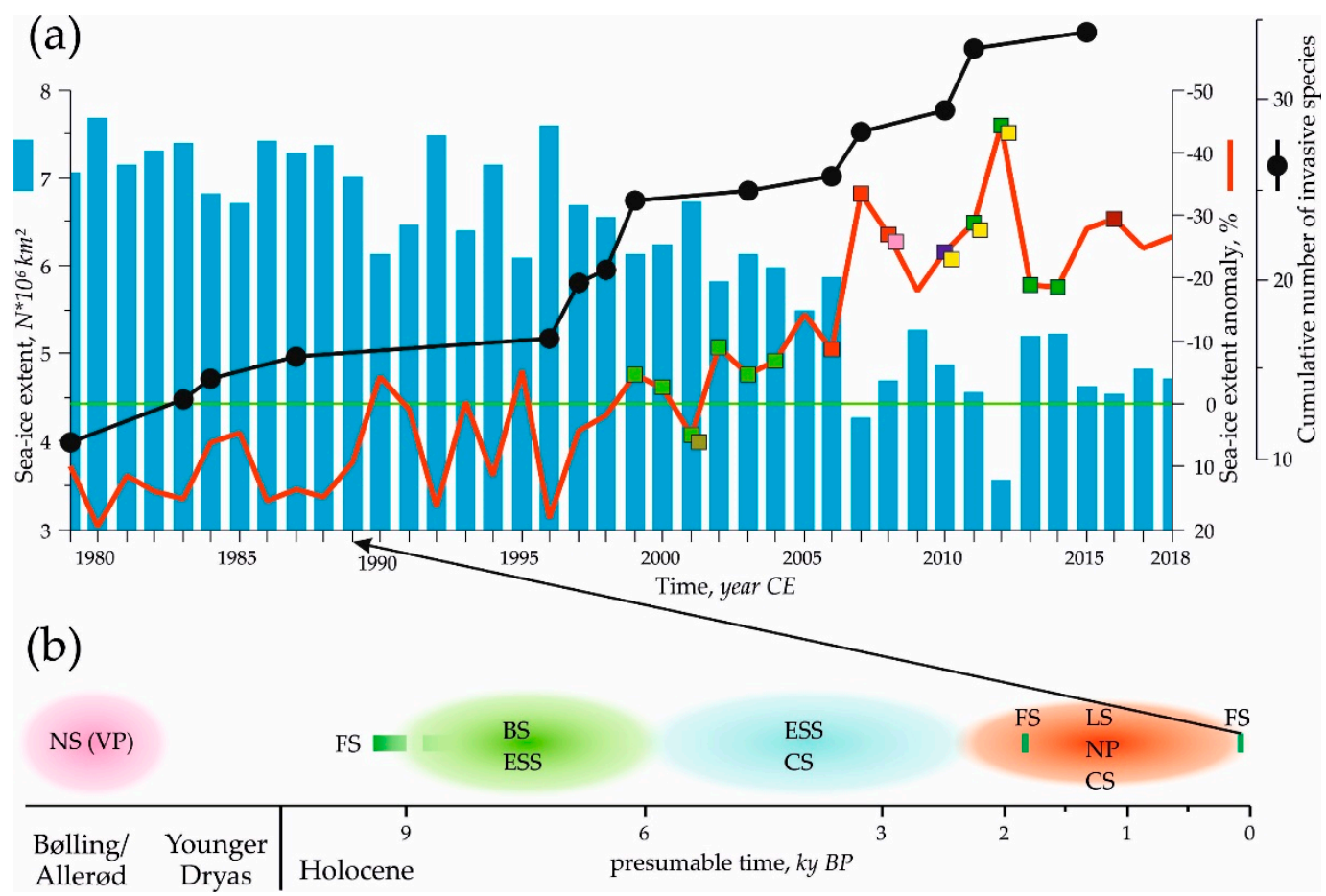

Figure 4. Records of N. seminae in the modern Arctic and North Atlantic and the Holocene sediments of the Arctic and Nordic Seas (see references in the Figure 3 caption). (a) N. seminae in the modern Arctic and North Atlantic: black-framed green and blue squares mark observations of N. seminae in the plankton, black-framed yellow squares mark observations of N. seminae in sediment trap NAP, black-framed red, brown, and rose squares mark observations of $N$. seminae in surface sediments. The Arctic sea-ice extent (vertical blue bars) and its anomalies (red line) are from [80]. Cumulative number of the invasive species (black dots and line) in the marine Arctic is from [81]. (b) N. seminae in the latest Pleistocene and Holocene sediments: green bars, green, blue, red, and pink ovals mark observations of N. seminae in the different areas within the different time intervals. NS(VP) is Norwegian Sea (Vøring Plateau), FS is Fram Strait, BS is Barents Sea, LS is Laptev Sea, ESS is East Siberian Sea, CS is Chukchi Sea, NP is North Pole.

Reid et al. [8] and Poulin et al. [51] note the unprecedented ice-free conditions in the Canadian Archipelago in 1998/1999 which could have been favorable for N. seminae dispersal to the Greenland Sea. Phylogenetic studies of N. seminae by Poulin et al. [51] do not support a long separation of the native North Pacific and newly established North Atlantic populations of the species. This can suggest a presumably recent migration of $N$. seminae to the subarctic areas of the North Atlantic. Invasion of species, both terrestrial and marine, has become one of main focuses of the ecosystem studies in recent decades; the number of publications on this topic has dramatically increased since the mid-2000s [82]. Chan et al. [81] provided data on invasions in the arctic and subarctic areas of the Atlantic realm from 1960 to 2015. The number of invasions increased sharply between 1996 and 1999 (Figure 4a). Appearance of N. seminae in the North Atlantic is within this event.

In summary, from the hydrological studies above, we could propose the oceanographic shift in the late 1990s, manifest as the higher transport of the warmer surface Pacific water to the Arctic together with a reduction of the Arctic ice (Figure 4a), may create a possibility for the native Subarctic Pacific diatom species N. seminae to settle in the subarctic areas of the Labrador Sea and Nordic Seas. Observations of N. seminae in the Holocene sediments of the Arctic and Nordic Seas (Figure 4b) can suggest the multiple events of the increased influence of the North Pacific water in the Arctic during the Holocene, not just during the recent Arctic warm climate amplification. However, additional high-resolution studies of the Holocene paleoenvironments are needed to prove a conclusion that N. seminae can appear in the North Atlantic and Arctic during such warm events. 
Another means for N. seminae to migrate into the Arctic and North Atlantic can be via ballast water discharge by ships routing from the North Pacific. Several studies have discussed such a possibility for phyto- and zooplankton, as well as zoobenthos [83,84]. Regarding the recent appearance of N. seminae in the Labrador Sea and Gulf of St. Lawrence, Reid et al. [8] and Poulin et al. [51] noted low shipping volumes through the Canadian Archipelago Passages and in the Labrador Sea at the end of 1990s; thus, it was unlikely to expect a substantial ballast water exchange there. We cannot exclude such a possibility but the $N$. seminae occurrence in the pre-industrial time may point to the preferably natural migration of the species during oceanographic/environmental changes, which possibly have connections with warming events.

Author Contributions: Conceptualization, A.M. and G.K.K.; writing-original draft preparation, A.M. and G.K.K.; writing-review and editing, A.M. and G.K.K.; visualization, A.M. All authors have read and agreed to the published version of the manuscript.

Funding: This research was funded by Shirshov Institute of Oceanology RAS project number 0128-2019-0011.

Acknowledgments: We gratefully acknowledge constructive criticism, valuable comments and suggestions by two anonymous reviewers which greatly improved the manuscript. We are cordially grateful to Longbin Sha, Department of Geography, Ningbo University, Ningbo, China, for providing a supplementary data file on the diatom species Neodenticula seminae distribution in the North Atlantic surface sediments. We are indebted to the MDPI English editing service for the very valuable assistance in the English language proofing. We thank Geosciences Editorial team for helpful support in publication of our paper.

Conflicts of Interest: The authors declare no conflict of interest. The funders had no role in the design of the study; in the collection, analyses, or interpretation of data; in the writing of the manuscript, or in the decision to publish the results.

\section{Appendix A}

Table A1. Distribution of diatom species Neodenticula seminae in surface sediment samples from the North Atlantic, the 51st cruise of the Russian research vessel Akademik Ioffe in 2016.

\begin{tabular}{llll}
\hline Latitude & Longitude & Station & N. seminae, $\%$ \\
\hline 55.0021 & -43.7569 & AI-3646 & 11.86 \\
58.2180 & -54.1686 & AI-3639 & 16.34 \\
59.1116 & -50.5108 & AI-3635 & 11.86 \\
59.9664 & -47.0353 & AI-3629 & 0 \\
59.8962 & -42.3150 & AI-3613 & 0 \\
59.5627 & -41.0077 & AI-3597 & 6.06 \\
59.5028 & -39.3311 & AI-3593 & 8.62 \\
59.4926 & -37.3242 & AI-3592 & 14.66 \\
59.5039 & -34.9820 & AI-3586 & 0 \\
59.5062 & -30.6606 & AI-3574 & 0 \\
59.5009 & -28.6663 & AI-3568 & 0 \\
59.4988 & -26.6601 & AI-3562 & 0 \\
59.4977 & -24.7053 & AI-3556 & 0 \\
59.4931 & -21.9865 & AI-3548 & 0 \\
59.4984 & -20.6946 & AI-3545 & 0 \\
59.5004 & -18.0003 & AI-3540 & 0 \\
59.5028 & -15.3330 & AI-3534 & 0 \\
59.5009 & -13.3339 & AI-3531 & 0 \\
59.4991 & -11.3338 & AI-3527 & 0 \\
59.4988 & -9.3336 & AI-3524 & 0 \\
59.5001 & -7.3344 & AI-3521 & 0 \\
59.4996 & -6.0041 & AI-3519 & 0 \\
59.5001 & -3.8321 & AI-3516 & 0 \\
61.0679 & -3.8666 & AI-3451 & sporadic specimen, but accepted as 1\% to draw Figure 2a \\
62.7388 & -8.4601 & AI-3464 & 0 \\
64.0252 & -12.6182 & AI-3485 & 0 \\
\hline
\end{tabular}

\section{References}

1. Renaut, S.; Devred, E.; Babin, M. Northward expansion and intensification of phytoplankton growth during the early ice-free season in Arctic. Geophys. Res. Lett. 2018, 45, 10590-10598. [CrossRef]

2. Intergovernmental Panel on Climate Change (IPCC). Fourth Assessment Report of the Intergovernmental Panel on Climate Change, IPCC (WG IEII); Cambridge University Press: Cambridge, UK, 2007; 976p. 
3. Gascard, J.C.; Zhang, J.; Rafizadeh, M. Rapid Decline of Arctic Sea Ice Volume: Causes and Consequences. Cryosphere 2019. [CrossRef]

4. Fernandez, L.; Kaiser, B.A.; Vestergaard, N. Marine invasive species in the Arctic. TemaNord $2014,547$. [CrossRef]

5. Stachowicz, J.J.; Terwin, J.R.; Whitlatch, R.B.; Osman, R.W. Linking climate change and biological invasions: Ocean warming facilitates nonindigenous species invasions. Proc. Natl. Acad. Sci. USA 2002, 99, 15497-15500. [CrossRef]

6. Occhipinti-Ambrogi, A.; Savini, D. Biological invasions as a component of global change in stressed marine ecosystems. Mar. Pollut. Bull. 2003, 46, 542-551. [CrossRef]

7. Starr, M.; Harvey, M.; Galbraith, P.S.; Gilbert, D.; Chabot, D.; Therriault, J.C. Recent intrusion of Labrador Shelf waters into the Gulf of St. Lawrence and its influence on the plankton community and higher trophic levels. In Theme Session on Environmental Influence on Trophic Interactions (N); CM 2002/N: 16; International Council for the Exploration of the Sea: Copenhagen, Denmark, 2002.

8. Reid, P.C.; Johns, D.G.; Edwards, M.I.N.; Starr, M.; Poulin, M.; Snoeijs, P. A biological consequence of reducing Arctic ice cover: Arrival of the Pacific diatom Neodenticula seminae in the North Atlantic for the first time in 800,000 years. Glob. Change Biol. 2007, 13, 1910-1921. [CrossRef]

9. Miettinen, A.; Koç, N.; Husum, K. Appearance of the Pacific diatom Neodenticula seminae in the northern Nordic Seas-An indication of changes in Arctic sea ice and ocean circulation. Mar. Micropaleontol. 2013, 99, 2-7. [CrossRef]

10. Matul, A.G.; Abelmann, A. Pleistocene and Holocene distribution of the radiolarian Amphimelissa setosa Cleve in the North Pacific and North Atlantic: Evidence for water mass movement. Deep-Sea Res. II 2005, 52, 2351-2364. [CrossRef]

11. Bjørklund, K.R.; Hatakeda, K.; Kruglikova, S.B.; Matul, A.G. Amphimelissa setosa (Cleve) (Polycystina, Nassellaria)-A stratigraphic and paleoecological marker of migrating polar environments in the northern Hemisphere during the Quaternary. Stratigraphy 2015, 12, 233-237.

12. Sha, L.; Jiang, H.; Seidenkrantz, M.S.; Knudsen, K.L.; Olsen, J.; Kuijpers, A.; Liu, Y. A diatom-based sea-ice reconstruction for the Vaigat Strait (Disko Bugt, West Greenland) over the last 5000 yr. Palaeogeogr. Palaeoclimat. Palaeoecol. 2014, 403, 66-79. [CrossRef]

13. Schlitzer, R. Ocean Data View. 2018. Available online: https://odv.awi.de (accessed on 22 March 2020).

14. Fragoso, G.M. Biogeography of Spring Phytoplankton Communities from the Labrador Sea: Drivers, Trends, Ecological Traits and Biogeochemical Implications. Ph.D. Thesis, University of Southampton, Southampton, UK, November 2016; 187p. (In Russian).

15. Wang, Y.; Xiang, P.; Kang, J.; Ye, Y.; Lin, G.; Yang, Q.; Lin, M. Microphytoplankton community structure in the western Arctic Ocean: Surface layer variability of geographic and temporal considerations in summer. Hydrobiologia 2018, 811, 295-312. [CrossRef]

16. Onodera, J.; Watanabe, E.; Harada, N.; Honda, M.C. Diatom flux reflects water-mass conditions on the southern Northwind Abyssal Plain, Arctic Ocean. Biogeosciences 2015, 12, 1373-1385. [CrossRef]

17. Polyakova, Y.I. The Eurasian Arctic Seas during the Late Cenozoic; Scientific World: Moscow, Russia, 1997; 145p.

18. Gusev, E.A.; Skolotnev, S.G.; Aleksandrova, G.N.; Bylinskaya, M.E.; Golovina, L.A.; Zaporozhets, N.I.; Laiba, A.A.; Lyapunoiv, S.M.; Radionova, E.P. Preliminary Results of the Study of Deep-Sea Sediments from the North Pole. Dokl. Earth Sci. 2008, 421, 897-901. [CrossRef]

19. Mukhina, V.V.; Dmitrenko, O.B. Microfossils in the upper Quaternary sediments of the Norwegian Sea (biostratigraphy and paleoceanology). Oceanology 2008, 48, 720-734. [CrossRef]

20. Bylinskaya, M.E.; Golovina, L.A.; Radionova, E.P.; Pokrovskii, B.G.; Lavrushin, V.Y. Paleoenvironments in the Fram Strait during Marine Isotope Stages 2-6 based on planktonic paleobiological and stable-isotope proxies and ice-rafted debris. Quat. Intern. 2016, 420, 272-279. [CrossRef]

21. Tsoy, I.B.; Obrezkova, M.S. Atlas of Diatom Algae and Silicoflagellates from Holocene Sediments of the Russian East Arctic Seas; V.I. Il'ichev Pacific Oceanological Institute branch Russian Academy of Sciences: Vladivostok, Russia, 2017; 145p. (In Russian)

22. Tsoy, I.B.; Obrezkova, M.S.; Aksentov, K.I.; Kolesnik, A.N.; Panov, V.S. Late Holocene Environmental Changes in the Southwestern Chukchi Sea Inferred from Diatom Analysis. Russ. J. Mar. Biol. 2017, 43, 276-285. [CrossRef] 
23. Matul, A.; Spielhagen, R.F.; Kazarina, G.; Kruglikova, S.; Dmitrenko, O.; Mohan, R. Warm-water events in the Fram Strait during the last 2000 years as revealed by different microfossil groups. Polar Res. 2018, 37. [CrossRef]

24. Locarnini, R.A.; Mishonov, A.V.; Baranova, O.K.; Boyer, T.P.; Zweng, M.M.; Garcia, H.E.; Reagan, J.R.; Seidov, D.; Weathers, K.; Paver, C.R.; et al. NOAA Atlas NESDIS 81. World Ocean Atlas 2018, Volume 1: Temperature; NOAA/NESDIS National Centers for Environmental Information: Silver Spring, MD, USA, 2019; p. 52.

25. Semina, G.I. A new species of genus Denticula Ktz. Bot. Contrib. Komar. Bot. Inst. USSR Acad. Sci. Div. Spore Plants 1956, 11, 82-84. (In Russian)

26. Karohji, K. Report from the "Oshoro maru" on oceanographic and biological investigations in the Bering Sea and northern North Pacific in the summer of 1955. IV. Diatom associations as observed by Underway Samplings. Bull. Fish. Sci. Hokkaido Univ. 1959, 9, 259-267.

27. Taniguchi, A.; Saito, K.; Koyama, A.; Fukuchi, M. Phytoplankton Communities in the Bering Sea and Adjacent Seas. I. Communities in Early Warming Season in Southern Areas. J. Oceanogr. Soc. Jpn. 1976, 32, 99-106. [CrossRef]

28. Alexander, V.; Cooney, R.T. Ice edge ecosystem study: Primary productivity, nutrient cycling, and organic matter transfer. In Final Report, Outer Continental Shelf Environmental Assessment Program, Research Unit 427; University of Alaska: Fairbanks, AK, USA, 1979; p. 166.

29. Phifer, L.D. The occurrence and distribution of plankton diatoms in the Bering Sea and Strait, July 26-August 24, 1934. In Report Oceanographic Cruise, U.S. Coast Guard Cutter Chelan, Bering Sea and Bering Strait, 1934, Part II(A); U.S. Goast Guard Headquarters: Washington, DC, USA, 1936; pp. 1-44.

30. Aizawa, C.; Tanimoto, M.; Jordan, R.W. Living diatom assemblages from North Pacific and Bering Sea surface waters during summer 1999. Deep-Sea Res. II 2005, 52, 2186-2205. [CrossRef]

31. Wang, Y.; Xiang, P.; Ye, Y.; Lin, G.; Yang, Q.; Lin, H.; Lin, M. Community structure and spatial-temporal variation of netz-phytoplankton in the Bering Sea in summer. Acta Oceanol. Sin. 2016, 35, 99-107. [CrossRef]

32. Obrezkova, M.S.; Tsoy, I.B. Diatom flora of the Holocene sediments of the East Arctic seas. Vestnik Dal'nevostochnogo Otdelenija Rossijskoj Akademii Nauk 2008, 1, 136-143. (In Russian)

33. Ren, J.; Gersonde, R.; Esper, O.; Sancetta, C. Diatom distributions in northern North Pacific surface sediments and their relationship to modern environmental variables. Palaeogeogr. Palaeoclimat. Palaeoecol. 2014, 402, 81-103. [CrossRef]

34. Takahashi, K. Seasonal fluxes of pelagic diatoms in the subarctic Pacific, 1982-1983. Deep-Sea Res. Part A 1986, 33, 1225-1251. [CrossRef]

35. Onodera, J.; Takahashi, K.; Honda, M.C. Pelagic and coastal diatom fluxes and the environmental changes in the northwestern North Pacific during December 1997-May 2000. Deep-Sea Res. II 2005, 52, 2218-2239. [CrossRef]

36. Takahashi, K. Siliceous microplankton fluxes in the eastern subarctic Pacific, 19821-986. J. Oceanogr. 1997, 53, 455-466.

37. Tsoy, I.; Shastina, V.V.; Biryulina, M.G. Seasonal Fluxes of microplankton in the Meiji Guyot Area (Northwestern Pacific). Russ. J. Mar. Biol. 1998, 24, 306-312.

38. Tsoy, I.B.; Wong, C.S. Diatom fluxes and preservation in the deep Northwest Pacific Ocean. In Proceedings of the 14th Diatom Symposium; Mayama, S., Idei, M., Koizumi, I., Koeltz, O., Eds.; Scientific Books: Koenigstein, Germany, 1999; pp. 521-549.

39. Takahashi, K.; Fujitani, N.; Yanada, M.; Maita, Y. Long-term biogenic particle fluxes in the Bering Sea and the central subarctic Pacific Ocean, 1990-1995. Deep-Sea Res. I 2000, 47, 1723-1759. [CrossRef]

40. Mochizuki, M.; Shiga, N.; Saito, M.; Imai, K.; Nojiri, Y. Seasonal changes in nutrients, chlorophyll a and the phytoplankton assemblage of the western subarctic gyre in the Pacific Ocean. Deep-Sea Res. II 2002, 49, 5421-5439. [CrossRef]

41. Shimada, C.; Tanaka, Y.; Tanimura, Y. Seasonal variation in skeletal silicification of Neodenticula seminae, a marine planktonic diatom: Sediment trap experiments in the NW Pacific Ocean (1997-2001). Mar. Micropaleontol. 2006, 60, 130-144. [CrossRef]

42. Jousé, A.P. Stratigraphic and Paleogeographic Studies in the Northwestern Part of the Pacific Ocean; Academy of Sciences of USSR: Moscow, Russia, 1962; 259p. (In Russian) 
43. Kanaya, T.; Koizumi, I. Interpretation of diatom thanatocoenoses from the North Pacific applied to a study of core V20-130 (Studies of a deep-sea core V20-130. Part IV). Sci. Rep. Tohoku Univ. Sec. Ser. (Geol.) 1966, 37, 89-130.

44. Jousé, A.P.; Mukhina, V.V.; Kozlova, O.G. Diatoms and silicoflagellates in the surface layer of sediments. In The Pacific Ocean, Microflora and Microfauna in the Recent Sediments of Pacific Ocean; Kort, V.G., Ed.; Nauka Press: Moscow, Russia, 1969; pp. 7-47. (In Russian)

45. Sancetta, C. Oceanographic and ecological significance of diatoms in surface sediments of the Bering and Okhotsk seas. Deep-Sea Res. 1981, 28, 789-817. [CrossRef]

46. Sancetta, C. Distribution of diatom species in surface sediments of the Bering and Okhotsk seas. Micropaleontology 1982, 28, 221-257. [CrossRef]

47. Kazarina, G.K.; Yushina, I.G. Diatoms in recent and Holocene sediments of the North Pacific and Bering Sea. Berichte zur Polarforshung 1999, 306, 120-133.

48. Caisse, B.A. Diatoms as Recorders of Sea Ice in the Bering and Chukchi Seas: Proxy Development and Application. Ph.D. Thesis, University of Massachusetts Amherst, Amherst, MA, USA, May 2012.

49. Ran, L.; Chen, J.; Jin, H.; Li, H.; Lu, Y.; Wang, K. Diatom distribution of surface sediment in the Bering Sea and Chukchi Sea. Adv. Polar Sci. 2013, 24, 106-112. [CrossRef]

50. Shao, L.; Lin, R.; Gao, Y.; Huang, D. Composition and distribution of diatom assemblages in the surface sediments of the Bering Sea. Adv. Polar Sci. 2013, 24, 1671-1674. [CrossRef]

51. Poulin, M.; Lundholm, N.; Bérard-Therriault, L.; Starr, M.; Gagnon, R. Morphological and phylogenetic comparisons of Neodenticula seminae (Bacillariophyta) populations between the subarctic Pacific and the Gulf of St. Lawrence. Eur. J. Phycol. 2010, 45, 127-142. [CrossRef]

52. Koç Karpuz, N.; Schrader, H. Surface sediment diatom distribution and Holocene paleotemperature variations in the Greenland, Iceland and Norwegian Sea. Paleoceanography 1990, 5, 557-580. [CrossRef]

53. Koç Karpuz, N.; Jansen, E. A high-resolution diatom record of the last deglaciation from the SE Norwegian Sea: Documentation of rapid climatic changes. Paleoceanography 1992, 7, 499-520. [CrossRef]

54. Andersen, C.; Koç, N.; Moros, M. A highly unstable Holocene climate in the subpolar North Atlantic: Evidence from diatoms. Quat. Sci. Rev. 2004, 23, 2155-2166. [CrossRef]

55. Witak, M.; Wachnicka, A.; Kuijpers, A.; Troelstra, S.; Prins, M.A.; Witkowski, A. Holocene North Atlantic surface circulation and climatic variability: Evidence from diatom records. Holocene 2005, 15, 85-96. [CrossRef]

56. Witon, E.; Malmgren, B.; Witkowski, A.; Kuijpers, A. Holocene marine diatoms from the Faeroe Islands and their paleoceanographic implications. Palaeogeogr. Palaeoclimat. Palaeoecol. 2006, 239, 487-509. [CrossRef]

57. Ran, L.; Jiang, H.; Knudsen, K.L.; Eiríksson, J. A high-resolution Holocene diatom record on the North Icelandic shelf. Boreas 2008, 37, 399-413. [CrossRef]

58. Krawczyk, D.W.; Witkowski, A.; Lloyd, J.; Moro, M.; Harff, J.; Kuijpers, A. Late-Holocene diatom derived seasonal variability in hydrological conditions off Disko Bay, West Greenland. Quat. Sci. Rev. 2013, 67, 93-104. [CrossRef]

59. Li, D.; Sha, L.; Li, J.; Jiang, H.; Liu, Y.; Wu, Y. Summer Sea-Surface Temperatures and Climatic Events in Vaigat Strait, West Greenland, during the Last 5000 Years. Sustainability 2017, 9, 704. [CrossRef]

60. Oksman, M. Diatom-Based Reconstructions of Climate and Ocean Conditions from Svalbard and Baffin Bay since the Last Glacial Maximum. PhD. Thesis, Faculty of Science of the University of Helsinki, Helsinki, Finland, 15 December 2017; 48p.

61. Bonnet, S.; de Vernal, A.; Hillaire-Marcel, C.; Radi, T.; Husum, K. Variability of sea-surface temperature and sea-ice cover in the Fram Strait over the last two millennia. Mar. Micropal. 2010, 74, 59-74. [CrossRef]

62. Werner, K.; Spielhagen, R.F.; Bauch, D.; Hass, H.C.; Kandiano, E.; Zamelczyk, K. Atlantic water advection to the eastern Fram Strait-Multiproxy evidence for late Holocene variability. Palaeogeogr. Palaeoclimat. Palaeoecol. 2011, 308, 264-276. [CrossRef]

63. Spielhagen, R.F.; Werner, W.; Sørensen, S.A.; Zamelczyk, K.; Kandiano, E.; Budeus, G.; Husum, K.; Marchitto, T.M.; Hald, M. Enhanced Modern Heat Transfer to the Arctic by Warm Atlantic Water. Science 2011, 331, 450-453. [CrossRef]

64. Min, S.K.; Zhang, X.; Zwiers, F.W.; Agnew, T. Human influence on Arctic sea ice detectable from early 1990s Onwards. Geophys. Res. Lett. 2008, 35, L21701. [CrossRef] 
65. Kinnard, C.; Zdanowicz, C.M.; Fisher, D.A.; Isaksson, E.; de Vernal, A.; Thompson, L.G. Reconstructed changes in Arctic sea ice over the past 1,450 years. Nature 2011, 479, 509-513. [CrossRef]

66. Maynard, N.G. Relationship between diatoms in surface sediments of the Atlantic Ocean and the biological and physical oceanography of overlying waters. Paleobiology 1976, 2, 99-121. [CrossRef]

67. Williams, K.M. Recent Arctic marine diatom assemblages from bottom sediments in Baffin Bay and Davis Strait. Mar. Micropaleontol. 1986, 10, 327-341. [CrossRef]

68. Schrader, H.; Swanberg, I.L.; Burckle, L.H.; Grønlien, L. Diatoms in recent Atlantic $\left(20^{\circ} \mathrm{S}\right.$ to $70^{\circ} \mathrm{N}$ latitude $)$ sediments: Abundance patterns and what they mean. Hydrobiologia 1993, 269, 129-135. [CrossRef]

69. Cremer, H. Distribution patterns of diatom surface sediment assemblages in the Laptev Sea (Arctic Ocean). Mar. Micropaleontol. 1999, 38, 39-67. [CrossRef]

70. Woodgate, R.A. Increases in the Pacific inflow to the Arctic from 1990 to 2015, and insights into seasonal trends and driving mechanisms from year-round Bering Strait mooring data. Progr. Oceanogr. 2018, 160, 124-154. [CrossRef]

71. Coachman, L.K.; Aagard, K. Transports Through Bering Strait: Annual and Interannual Variability. J. Geophys. Res. 1988, 93, 15535-15539. [CrossRef]

72. Roach, A.T.; Aagaard, K.; Pease, C.H.; Salo, S.A.; Weingartner, T.; Pavlov, V.; Kulakov, M. Direct measurements of transport and water properties through the Bering Strait. J. Geophys. Res. 1995, 100, 18443-18457. [CrossRef]

73. Steele, M.; Morison, J.; Ermold, W.; Rigor, I.; Ortmeyer, M. Circulation of summer Pacific halocline water in the Arctic Ocean. J. Geophys. Res. 2004, 109, C02027. [CrossRef]

74. Sumata, H.; Shimada, K. Northward Transport of Pacific Summer Water along the Northwind Ridge in the Western Arctic Ocean. J. Oceanogr. 2007, 63, 363-378. [CrossRef]

75. Hill, V.; Ardyna, M.; Lee, S.H.; Varela, D.E. Decadal trends in phytoplankton production in the Pacific Arctic Region from 1950 to 2012. Deep-Sea Res. II 2018, 152, 82-94. [CrossRef]

76. Yashayaev, I.; Seidov, D.; Demirov, E. A new collective view of oceanography of the Arctic and North Atlantic basins. Progr. Oceanogr. 2015, 132, 1-21. [CrossRef]

77. Falck, E. Contribution of waters of Atlantic and Pacific origin in the Northeast Water Polynya. Polar Res. 2001, 20, 193-200. [CrossRef]

78. Jones, E.P.; Swift, J.H.; Anderson, L.G.; Lipizer, M.; Civitarese, G.; Falkner, K.K.; Kattner, G.; McLaughlin, F. Tracing Pacific water in the North Atlantic Ocean. J. Geophys. Res. 2003, 108, 3116. [CrossRef]

79. Dodd, P.A.; Blæsterdalen, T.; de Steur, L.; Karcher, M.; Hattermann, T. Pacific water in the Arctic Ocean and Fram Strait. FRAM FORUM 2018. pp. 36-41. Available online: https://www.framsenteret.no/2018/04/pacificwater-in-the-arctic-ocean-and-fram-strait. (accessed on 22 March 2020).

80. Snow and Ice, National Climatic Data Center, NOAA. Available online: https//www.ncdc.noaa.gov/snowand-ice (accessed on 22 March 2020).

81. Chan, F.T.; Stanislawczyk, K.; Sneekes, A.C.; Dvoretsky, A.; Gollasch, S.; Minchin, D.; David, M.; Jelmert, A.; Albretsen, J.; Bailey, S.A. Climate change opens new frontiers for marine species in the Arctic: Current trends and future invasion risks. Glob. Change Biol. 2019, 25, 25-38. [CrossRef]

82. Sorte, C.J.B. Synergies between Climate Change and Species Invasions: Evidence from Marine Systems. In Invasive Species and Global Climate Change; Ziska, L.H., Dukes, J.S., Eds.; Cabi Invasive Species Series 4; CPI Group (UK) Ltd.: Croyton, UK, 2014; pp. 101-116.

83. Chan, F.T.; Bailey, S.A.; Wiley, C.J.; MacIsaac, H.J. Relative risk assessment for ballast-mediated invasions at Canadian Arctic ports. Biol. Invasions 2013, 15, 295-308. [CrossRef]

84. Holbech, H.; Pedersen, K.L. Ballast Water and Invasive Species in the Arctic. In Arctic Marine Resource Governance and Development (Springer Polar Sciences); Vestergaard, N., Kaiser, B.A., Fernandez, L., Nymand Larsen, J., Eds.; Springer: Heidelberg, Germany, 2018; pp. 115-137.

(C) 2020 by the authors. Licensee MDPI, Basel, Switzerland. This article is an open access article distributed under the terms and conditions of the Creative Commons Attribution (CC BY) license (http://creativecommons.org/licenses/by/4.0/). 